\title{
A Critical Look at Race and Language as a Method of Establishing Personal Identity in Japan and Korea
}

\section{Lee Hatch Flake}

Nagasaki University Japan

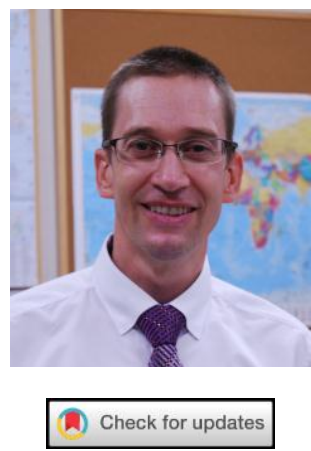

\begin{abstract}
The author raises the question of race and language as a valid concept for biological or social classification and expands this point to inquire how Japanese and Korean societies determine who belongs as societal members. Marginality and ambiguity create separate criteria for determining who is Japanese or Korean.
\end{abstract}

Keywords: Race, Society, Language, Classification.

\section{Introduction}

The author having lived extensively in Japan and Korea for over two decades as an expatriated American often questions his cultural identity as the attachment to his homeland has dissolved over the years. While striving for cultural acceptance in Japan and Korea the author has found that acceptance is exclusive to ethnic orientation and appearance over cultural knowledge or language skill. Caucasian colleagues of Western lineage who have taken on Japanese or Korean citizenship have also shared experiences on the lack of cultural acceptance and overall disbelief of citizenship based entirely on physical appearance. Western expatriates must carefully consider the political and social ramifications of naturalizing as a Korean or as a Japanese. Taking on citizenship is a serious matter especially since neither Japan nor Korea recognizes dual or multiple citizenship unless one is a minor. Renunciation of all former citizenship means that one must re-evaluate their personal identity and connection to their homeland. Likewise, one's "new" identity as a Japanese or Korean citizen is potentially a challenge for social acceptance since nationality in the social definition is determined predominantly by race. Although politically accepted as a citizen, a naturalized Westerner may never become fully accepted by society and be condemned to reside as a perpetual foreigner.

The author studied East Asian Cultural Anthropology at universities in Korea and Japan and majored in Asian Studies and Japanese at his alma mater in the United States. The author has also worked facilitating courses at universities and public schools in Japan and Korea further providing cultural perspective based on research, experience and observation.

Although Japan and Korea are referred to in this article, the concept of race and language as a cultural identifier is certainly not exclusive to these countries. 


\section{Questioning Race as a Valid Concept for Biological Classification}

Human beings, in all societies, try to impose order and classify the universe around them. In all languages, objects of the natural world are named. Everything, from the smallest plants and animals to every river and mountain all have names. However, the imposed order and classification of the natural universe is more than merely assigning names. Human beings also find it necessary to determine what things belong together based upon observed similarities of qualities between plants and animals. Having an object named and categorized in a certain group serves to establish the identity of that object. However, even those who are doing the classifying are part of the natural world being classified. Therefore, humans are also subject to classification (Klass, 1971). Humans use race as a classification method to establish identity. There are many variables to consider in the classification of humans and whether it is a valid concept. With the consideration of all the complexities and contradictions within classification systems such as cultural implications and historical and modern problems, one comes to the conclusion that human classification based upon race is, in fact, not a valid biological classification concept.

Races are defined by sociologists as being "groups of people characterized by shared inherited physical traits that distinguish them from other groups." (Rose, 1986). Race, in many ways is synonymous with the term ethnicity. Both terms are used to describe the awareness of differences among people. Ethnic groups are those within a larger society that retain distinctive cultural and social traits. Although every person is physically unique, gross similarities of skin color, hair texture and other traits often lead us to categorize people according to certain shared physical characteristics (Horton, 1976).

Modern classification of human beings is most often credited to the work of Carolus Linnaeus, who divided humans according to skin color, and reported that there were four divisions, or races: African, European, Asian, and American-Indian (Klass, 1971). However, Linnaeus classification for races was challenged by Johann Friedrich Blumenbach, who in 1775 proposed that humans should be divided into five races: Caucasian, Mongolian, Ethiopian, Malayan, and American. Nevertheless, even Blumenbach's theory for classification has proven unsatisfactory due to certain groups that don't "fit" into his divisions. To compensate for these problems, terms such as "Mongolian-like" are used to describe East Asian, Siberian, American-Indian or Polynesian people who are not classifiable according to Blumenbach's theory (Klass, 1971). In addition to these problems of racial classification, people who are of a "mixed race" also encounter social as well as scientific difficulties identifying themselves unambiguously. Therefore, race is an invalid biological concept because of the many sub-race variations.

In modern scientific studies, Blumenbach's theory of five race groups has been replaced by the theories of Lewontin. According to Lewontin, the actual levels of genetic variations between and within seven designated "races" are greater within these races than between them. His studies indicate that race explains only about ten percent of human genetic diversity. This low number indicates that race is not an accurate description of human variation. Therefore, race is a product of human minds and not of nature, and "...race fails to describe variation accurately [because] much variation is continuous, whereas race is a discrete unit" (Relethford, 1996).

Other reasons that race is not valid as a biological classification concept is that race has cultural and social implications. Therefore, its classification presents many problems for interpretation. Human classification of race throughout history has often had undertones of nationalistic adventures. Race is often used for biological as well as social distinctions. Aristotle, a Greek philosopher, indicated with his essentialistic concept that all beings, including humans, must have their "perfect type" and he placed favoritism toward the Greeks as being the "perfect type." Linneous in the 1700's also classified human behavioral attributes with a heavy bias against groups other than Europeans. During the 1900's, Morton used the study of cranial size variations for the basis of his classification theory. However, he was selective about having larger skull sizes to support Europeans in his experiments, which dramatically and artificially altered the results of his studies. His studies as well as Broca's studies of cranial shape used to determine race have been proven to be inconclusive. With undertones of racism, Boas conducted "intelligence tests" on immigrants in an attempt to prove his ideas that roundheaded people are superior in intellect (Moeran, 2007).

Modern classification techniques, although more detailed and varied in nature, are still inconclusive as established criteria for determining race identity. Modern classification techniques include comparative studies of blood type, hair type, DNA, and Rh factor (Marks, 1995). Mendel's law of segregation published in 1865 is still a source for chromosome study and modern classification ever since its rediscovery in the 1900 s (Relethford, 2012). There have also been various linguistic studies used in the attempt to classify of race (Cavalli-Sforza, 1991). Other studies consist of a more scientific approach to traditional race classification based upon skin color. Differences in skin color reflect differences in the rates of melanin synthesis (Richards, 1998). By theory, the skin pigmentation and its reaction to ultraviolet radiation from the sun has an influence on the distribution of race populations. Melanin pigment of the skin protects against ultraviolet radiation and is more 
evident in populations that are in geographic locations which heavily expose such populations to radiation from the sun (Maged, 1997).

Historical and social studies of human classification have often continued to breed segregation. It is easier to identify an individual on the basis of "race" as a title or a name without consideration to the individual. Therefore, a racial name may also be used to strip away identity and reduce a person to an object or to an inanimate entity — completely disposable and convenient to discriminate (Franti, 1994). Much like a camera cannot take a picture of itself, perhaps it is impossible for an individual to know who they are until they have an understanding of who they are not (Freilich, 1972). We find out about ourselves through others. Race is not a valid biological concept because of cultural implications as well as historical and modern problems associated with the classification of race.

Race as a classification method promotes discrimination and "othering" of marginal society members. This is also very much evident in modern societies across the globe. As Donna Nakazawa wrote in the July 6, 2003 edition of Parade Magazine, many governments do not readily acknowledge cultural diversity as those of mixed-race are not given the liberty to identify themselves as belonging to more than one race. The "you can't be both" mentality is manifested when filling out forms requesting information on race or nationality. Boxes might be labeled "black" "white" "Asian" when one of mixed-race is forced to mark only one choice and "other" or multiple selections are not an option, one's identity becomes institutionally challenged (Nakazawa, 2003).

Scientists have acknowledged that there is more variation within race than between race further suggesting that racial classification is not valid. In social terms as well, variations in what is considered "dark-skinned" or "black" is a source for bullying and discrimination even among dark-skinned social groups. Flake (1998) in her novel "The Skin I'm In" writes about how African-American youth interpret different hues of dark skin color as labels and criteria for discrimination suggesting that there are different degrees of "blackness" in reference to both skin color and character.

Thomas (2007) in his book "Turning White" challenges skin color as racial identification when considering skin color being altered through skin pigmentation disorders such as vitiligo. Vitiligo is a condition where melanocytes, the cells that promote skin pigmentation, shut down leaving sections of skin void of color. Universal vitiligo encompasses most of the body and such depigmentation renders an individual completely white due to the absence of skin color. Albinos are also void of skin pigmentation due to a lack of melanocytes and the enzyme tyrosinase from birth. Albinos and individuals with vitiligo have suffered social ostracization and discrimination throughout history. In the $18^{\text {th }}$ century, social scientists such as Abbe Demanet, Comte de Buffon, and Claude-Nicolas Le Cat attempted to categorize albinos as a separate race further complicating the validity of race as a quantifier of humans (Blakemore and Jennett, 2001).

\section{Who is Korean in today's Korea? Who Is Japanese in today's Japan?}

In order to determine who is Japanese or Korean and who is not Japanese or Korean from the native resident viewpoint, it is best to have an understanding of their respective cultures. It is difficult for Westerners to see Japanese or Koreans entirely as the Japanese and Koreans see themselves. It's difficult for any individual to see themselves and acknowledge their beliefs and culture until in a situation where they are in a culture or environment that is other than what they are accustomed to. In other words, "you don't know who you are until you know who you aren't." This concept can be viewed to breed separation, but it is by labeling that a society and an individual are created. Labeling is a necessary initial step in understanding anything at all. When questioning what $\mathrm{X}$ is, it is necessary to formulate an answer by first giving a name to $\mathrm{X}$ (Lebra, 1996)

Labeling by relations and patterns of social interaction provide references for belongingness. Cultural anthropologist Takie Lebra Sugiyama explains in detail about how the individual is who he/she is by formal and informal references to blood ties, geographical ties, and occupational ties. These references are distinct and necessary for creating identity for the individual and are relative to how the Japanese and Koreans perceive who they are. Society determines and prescribes the value to the categories. Free society is self-governing and determines the mind-set, law-with its informal and formal restraining devices, customs, and behavior of the individual society members. How the individual fits into the category, which is described by Dr. Lebra as being the "frame," determines if he/she is Japanese or Korean. Moeran and Valentine (1992) also describe those who do not fit the description of what a society has prescribed as being Japanese or Korean are described as being marginals or outsiders. There are different degrees of marginality and outsiders (Moeran, 2007). For example, an individual who is of mixed Korean or Japanese and foreign parentage is marginal rather than being an outsider, or a "pure" foreigner. This analysis leaves an impression that the Koreans and Japanese determine who is Korean or Japanese entirely by appearance, however, distrust of ambiguity in belonging is manifested by the Japanese opinion of Koreans and other Asians.

Who exactly is marginal is determined by society. Dr. Lebra stated that Japanese who don't act like Japanese are not readily accepted as being Japanese. Examples, as given in the anthropological studies are the 
cases of "returnees." After living abroad, those Japanese found that their perception and behavior slightly altered and differed from other Japanese upon returning to Japan. Dr. Lebra explained this concept by the description of how foreigners are expected to act like foreigners. "Japanese expect foreigners in Japan to retain their foreign identity... Japanized foreigners, who may be liked by their Japanese friends, to be sure, nevertheless often disturb the sense of belongingness held by most Japanese" (Lebra, 1996). This can also be argued about returnees in Korea. The author associated with Korean returnee students at Keimyung University and was told of their experiences of being bullied by classmates due to their Korean-ness being challenged by native residents. Most of the Korean returnees were from the Soviet Union; however, Korean returnees were also composed of long-term residents of Canada, Japan, and the United States.

International marriages and other foreign contact label the individual separated as a marginal, marrying a foreigner from a low-status country may render one as an outsider than a marginal. How the children of international marriages are received by society also is manifested by the titles that such children have been given by society. In Korea 혼혈 hon hyeol or hon hyara meaning, "mixed blood" is common but can also be interpreted to mean "half-blood" as one can see in the Korean title of J.K. Rowling's Harry Potter series: Harry Potter and the Half-Blood Prince 해리포터와혼혈왕자. However 혼혈 has in recent years been replaced by the title of 반 or 절반 meaning "half". The author assumes that there is nothing intrinsically wrong with the 혼혈 expression when compared to the expression tuigi 틔기 which is inherently derogatory and refers directly to children of mixed blood. Half and 혼혈 hon hyeol are debatably descriptive; however, both expressions represent the fact the Koreans create a reference only to the "half" that is Korean without acknowledgment that the child is representative of two cultures.

Likewise, in Japan, children of international marriage were once given the label of 合の子 ai no ko. Derogatory expressions such as 何処の馬の骨か分からない doko no uma no hone ka wakaranai are found in Japanese literature. In modern times 合の子 has been updated to 混血 kon ketsu meaning "mixed blood" which has been further updated to ハーフ or "half." Neither Japanese nor Koreans tend to be aware of the negative nuance associated with this term. Half which is derived from half-breed or half-blood carries the nuance of being unfinished, incomplete or not entire-perhaps the equivalent of 中途牛端 or 何か足らない in Japanese. Although no ill intention may be given by Koreans and Japanese as they use this term liberally as a label, both Koreans and Japanese are subconsciously only acknowledging the Japanese or Korean "half" of the individual. The politically correct term for a child of an international marriage is "double" or "multi-national" since these terms acknowledge the entirety of the individual. Nevertheless, having no label at all would represent true cultural acceptance and end discrimination as the individual would not be seen as nor judged by the color of his or her skin or ethnic orientation.

The concept of "half" also represents how international marriage causes a cultural pollution resulting in marginality (Kondo, 1990). The author, having interviewed individuals of mixed parentage in Japan and Korea has found that there is divided opinion as to the offensiveness of the expression "half" as a title. Most do not find the term offensive; nevertheless, those that do find the term offensive are very much vocal about correcting the use of the title and are engaged in a never-ending battle against society as the term has become so widely accepted.

By experience, ethnic origin and skin color are determining factors for treatment as a true resident of Japan or Korea. The terms gaijin 外国人 or 외국인 weigukin refers exclusively to foreigners who are Caucasian further suggesting a covert sense of belongingness based on ethnic ties. In the late 80s, Caucasian foreigners who were able to converse fluently in Japanese were labeled henna gaijin 変な外人. Once a popular term, this remained in use until the mid 90s which is now replaced by the perennial Nihongo wa o-jozu desu 日本語はお上 手です which appears on the surface to be a compliment is nevertheless potentially highly offensive to one who has taken on Japanese citizenship or has been born, raised and educated in Japan and otherwise maintains a selfidentity of being Japanese. As Yoshikazu Matsui writes, further offense can be taken if this compliment is given to those who have endeavored through years of study to master the Japanese language and are told Nihongo wa o-jozu desu 日本語はお上手です in response for both delivering a speech in Japanese as well as for uttering a simple greeting. Based on ethnic appearance, one is treated as perpetual foreigner regardless of language ability (Matsui, 1992).

Acceptance of an individual as being Japanese or Korean is often based primarily upon appearance and superficially upon language skills. Somewhat debatable perhaps, but this provides an interesting background for another group who are of mixed Japanese or Korean and foreign parentage. Appearance already creates a level of marginality in most cases which can only be solidified by language skill. Those who are not of mixed lineage and rely entirely on language have to continually "prove" their identity (Keene, 1999). This author concurs as it 
is generally assumed by Japanese and Koreans that Westerners are not able to converse in Japanese or Korean. Being asked "Can you speak Japanese or Korean?" is merely to reconfirm the assumption that Westerners cannot speak languages other than English. Assumed English ability is also an overgeneralized assumption considering the variety of languages that Caucasians may speak as a mother language. English is a second language to many Europeans who otherwise are assumed to be proficient in the language due to appearance as Westerners. According to naturalized Japanese citizen Debito Arudo, having Japanese language ability may serve as a qualifier to entitlement for "Japaneseness." However, language ability and "Japaneseness" are not a racially-based social construct, as more non-native speakers and multiethnic natives continue to appear (Arudo, 2007).

Demographic changes in Japan are occurring. An increasing number of foreigners are naturalizing and becoming Japanese citizens as reported in the article The New Faces of Japan in the September 2006 edition Newsweek Magazine. Society accepting the citizenship of naturalized Japanese citizens is the true challenge for achieving global awareness (Newsweek, 2006).

Besides language and appearance another form of establishing identity which is culturally important in any society is the individual's name. If the individual's name is a Japanese or Korean name, it creates a notable level of acceptance within the marginality. Even by the author's experience of having the name of "Lee," while residing in Korea, the author was often asked to repeat the name out of the disbelief of the listener. When the name "Lee" is finally accepted, it is usually followed by the statement describing how Lee is a common family name in Korea- even ludicrous remarks and inquiries of whether or not the author was of Korean ancestry. If the individual's name is a Korean name or a Japanese name, it creates a notable level of acceptance within the marginality.

Historically, the Japanese government required foreigner nationals of countries occupied by the Japanese military to renounce their former citizenship as well as renounce their name for a Japanese name. Later, with the end of World War II, names written in Chinese ideograph characters or kanji following the pronunciation of a foreigner's original name were acceptable. In the wake of World War II, taking on Japanese citizenship was more of a choice than a matter of being forcibly assimilated; however, the practice of using such 当て字 ateji characters has recently gone retro by requiring all those whom take on Japanese citizenship to use only standard Japanese names. In the past only foreigners that were forcefully assimilated as Japanese had their names changed according to this standard. During the Japanese military occupation of Korea and Taiwan, the Japanese government forced Koreans and Taiwanese to have Japanese names in an attempt to eclipse their nationality and remove ambiguity and forcing a merge in culture. Japanese history and treatment of the Ainu and Ryukyu people also reflects the politically supported campaign to remove ambiguity and force assimilation.

In 2015, Ariana Mamiko Miyamoto from Nagasaki prefecture won the title of Miss Nagasaki. In the same year, Miyamoto went on to become the first multiracial woman to be crowned Miss Universe Japan. Although she represented Japan at the Miss Universe 2015 pageant, she soon encountered heavy discrimination and disapproval of her win through online social media due to her multiracial "hafu" appearance (Lies and Ito, 2015). Miyamoto was the only black girl in her class while growing up in Sasebo, Nagasaki (Fritzpatrick and Macfarlan, 2015). In interviews she recalled that "whenever the teacher told us to hold hands, other children thought my black skin would rub off on them, so they said, 'don't touch me”" (CBS News, 2015). Miyamoto was often shunned because of her skin color as she grew up in Japan (Nagata, 2015). Classmates and their parents used the derogatory term "kurumbo" to refer to her (Wesby, 2015).

In 2016, Tokyo native Priyanka Yoshikawa was crowned Miss World Japan. Yoshikawa, like Miyamoto, was bullied for her skin color. In a 2016 interview with Hindustan Times, Yoshikawa stated that "...there was a time as a kid when I was confused about my identity, but I've lived in Japan so long now I feel Japanese" (Hindustan Times, 2016). Yoshikawa, in the same interview described how being "hafu" does not mean that one is not Japanese and openly challenged the Japanese mindset of what it means to be a "pure" Japanese .

Social media in Japan is in an uproar complaining that all Miss Japan contestants should be "pure" Japanese. Neither Miyamoto nor Yoshikawa are recognized by the Japanese public as Miss Japan within Japan as the media has avoided coverage of the event in an effort to favor the "pure" Japanese who, according to the media, are more deserving to be crowned "Miss Japan" (Japan Times, 2016). The author, residing in Nagasaki, is appalled at how the local media has blatantly ignored Miyamoto winning both the title of Miss Nagasaki and Miss Universe Japan. Japanese media has ignored both Miyamoto and Yoshikawa to the extent that neither are recognized as Miss Japan in Japan. Ironically, foreign tourists visiting Japan are the first to recognize Miyamoto and Yoshikawa as Miss Japan. Japanese claim to be multicultural by embracing English language studies and opening the country to tourists for the Japan experience, but Japan has a long way to go in embracing racial diversity within the country. The lack of public acceptance of a multi-racial Miss Japan is a manifestation of a greater social dilemma on the acceptance of marginalized societal members.

There are various levels of marginality which are controlled by society and by the disposition of the 
individual Japanese and Korean society member. The latter is evident in examples of Caucasian Westerners who were raised in Korea or Japan, growing up as Japanese or Korean and are Japanese or Korean by all description accept for appearance. Being of Caucasian or dark-skinned ancestry instead of Asian descent has set the level of marginality to its own category which is closer to an outsider than even a "pure" marginal. Apparently, as also in the case of other Asians in Japan or Korea, neither language nor cultural understanding is a strong enough category to allow foreigners in Japan or Korea to be accepted as being Japanese or Korean.

\section{Survey Results: Student Opinion}

On November $11^{\text {th }}$ and $13^{\text {th }}$ of 2013 and January $6^{\text {th }}$ of 2014 , the author took separate surveys on student opinion on the nationality and cultural identity of twenty-one widely known individuals in Japanese society. Survey was conducted with students in the Faculty of Environmental Science and students in the Economics Faculty at Nagasaki University. Students polled were junior university students. Of the 220 students that responded, 77 were female and 143 were male. Not all participants responded and many responded in partial answers as can be seen in the data. In retrospect, the author feels that responses were perhaps given merely to complete the task without careful consideration as to the importance of the poll. This research is an extension of a similar study conducted by naturalized Japanese citizen Arudou David on April 25, 2007. For reference, the presentation on Dr. Arudou's research is available online at www.debito.org/ICU042507.ppt

Students polled were asked to explain "what is a Japanese?" No remarks were made or direction given nor were answers or responses solicited. Students were given freedom to determine their own criteria and discuss among themselves what characteristics and requirements constitute a Japanese citizen. Answers and explanations given on "what is a Japanese?" were diverse. In no order of preference or importance, the most common answers include the following:

A person who has lived in Japan 日本に住んだことがある人

A person who considers him/herself "Japanese" 自分が「日本人だ」と思う人

A person who has Japanese citizenship 日本国籍を有する人

A person who has assimilated into Japan 日本に溶け込んでいる人

A person born in Japan 日本で生まれた人

A person who has spent the majority of his/her life in Japan 人生の大牛を日本で過ごした人

A person who likes Japan 日本が好きな人

A person who has Japanese blood 日本の血が入っている人

A person who knows a lot about Japan 日本について詳しい人

A person using Japanese in everyday conversation 日常会話で日本語を使う人

A person with Japanese parents/grandparents 兩親・祖父母に日本人がいる人

A person who is proud of Japan 日本について誇りを持つ人

Opinions were capricious and diverse, but most responses favored blood ties such as race and ethnicity as the determining criteria for determining "what is a Japanese?" Students also had ludicrous responses such as "the ability to use chopsticks" or "can eat sushi and natto" as determining criteria.

Samples of Japanese societal members and people that have appeared in the Japanese media were used for survey material. Students were given a choice to choose "Japanese" "Foreigner" or "Don't Know" for their response. The researcher instructed the students to not give too much thought in their response, but to follow their first impression.

The correct response for who is "Japanese" is based on criteria of citizenship determined by legally accepted governmental interpretation. Maintaining a Japanese passport and having a residency registration or juminhyo 住民票 and being included in a citizen’s registry koseki 戸籍 are the legal requirements determining citizenship. Although vague, debatable, and potentially unknown by the students, for research purpose serves as the criteria used for determining the correctness of the student's response.

The following society members are of Japanese citizenship, including those of mixed blood or those who have naturalized: Rie Miyazawa, Anna Umemiya, Sachio Kinugasa, Fujimori Alberto, Konishiki, Akebono, Ramos Rui, Antonio Inoki, Eri "Rola" Sato, Marutei Tsurunen, Shintaro Ishihara, and "Tama-chan". Some of the individuals mentioned have either taken on citizenship kika 㷌化 in their lifetime or are Japanese but of mixed lineage; however all are Japanese based on the criteria of having citizenship and maintaining a juminyo or koseki:

The following society members are not Japanese due to possessing neither citizenship nor a juminhyo. The following individuals are of “permanent resident" zainichi eijusha 在日永住者 status, but maintain foreign 
citizenship: Akiko Wada, Lee Flake (the author), and Sadaharu Oh.

Table-1. Study on Social Acceptance: "Who is Japanese?"

\begin{tabular}{l|l|l|l|l|l}
\hline Societal Member & Japanese & Foreigner & Don't Know & No Response & Correct Response \\
\hline Akiko Wada & $133(60 \%)$ & $29(13 \%)$ & $35(16 \%)$ & $23(11 \%)$ & Foreigner (permanent res.) \\
\hline Rie Miyazawa & $209(95 \%)$ & $4(2 \%)$ & $7(3 \%)$ & -- & Japanese (mixed blood) \\
\hline Anna Umemiya & $182(83 \%)$ & $8(3 \%)$ & $21(10 \%)$ & $9(4 \%)$ & Japanese (mixed blood) \\
\hline Sachio Kinugasa & $81(37 \%)$ & $35(16 \%)$ & $42(19 \%)$ & $62(28 \%)$ & Japanese (mixed blood) \\
\hline Sadaharu Oh & $132(60 \%)$ & $53(24 \%)$ & $31(14 \%)$ & $4(2 \%)$ & Foreigner (permanent res.) \\
\hline Alberto Fujimori & $71(32 \%)$ & $83(38 \%)$ & $44(20 \%)$ & $22(10 \%)$ & Japanese (naturalized) \\
\hline Konishiki & $123(56 \%)$ & $12(6 \%)$ & $18(8 \%)$ & $67(30 \%)$ & Japanese (naturalized) \\
\hline Akebono & $134(61 \%)$ & $33(15 \%)$ & $33(15 \%)$ & $20(9 \%)$ & Japanese (naturalized) \\
\hline Ramos Rui & $115(52 \%)$ & $52(24 \%)$ & $25(11 \%)$ & $28(13 \%)$ & Japanese (naturalized) \\
\hline David Aldwinkle & $10(5 \%)$ & $109(49 \%)$ & $98(45 \%)$ & $3(1 \%)$ & Japanese (naturalized) \\
\hline Antonio Inoki & $117(53 \%)$ & $19(9 \%)$ & $21(10 \%)$ & $63(28 \%)$ & Japanese (returnee) \\
\hline Eri “Rola” Sato & $57(26 \%)$ & $74(33 \%)$ & $83(38 \%)$ & $6(3 \%)$ & Japanese (naturalized) \\
\hline "Neko" Hiroshi & $135(61 \%)$ & $35(16 \%)$ & $19(9 \%)$ & $31(14 \%)$ & Japanese (--) \\
\hline Osamu Shimomura & $215(97 \%)$ & $2(1 \%)$ & $3(2 \%)$ & -- & Japanese (--) \\
\hline Marutei Tsurunen & $95(43 \%)$ & $88(40 \%)$ & $30(14 \%)$ & $7(3 \%)$ & Japanese (naturalized) \\
\hline Donald Keene & $39(18 \%)$ & $75(34 \%)$ & $56(26 \%)$ & $50(22 \%)$ & Japanese (naturalized) \\
\hline Kent Derricott & $19(8 \%)$ & $120(55 \%)$ & $40(18 \%)$ & $41(18 \%)$ & Foreigner \\
\hline Shintaro Ishihara & $218(99 \%)$ & -- & $2(1 \%)$ & -- & Japanese \\
\hline Fusako Shigenobu & $134(61 \%)$ & $2(1 \%)$ & $22(10 \%)$ & $62(28 \%)$ & Japanese (--) \\
\hline Lee Flake & $54(25 \%)$ & $110(50 \%)$ & $34(15 \%)$ & $22(10 \%)$ & Foreigner (permanent res.) \\
\hline “Tama-Chan" & $25(11 \%)$ & $2(1 \%)$ & $98(45 \%)$ & $95(43 \%)$ & Japanese (--) \\
\hline Soure: Student survey 0 & &
\end{tabular}

Source: Student survey conducted by Flake, L. at Nagasaki University on 2013.11.11-13 and 2014.1.6

Of the society members mentioned, Kent Derricott is the only individual not of Japanese citizenship nor of permanent residency status. Other individuals mentioned fall into a dubious grey legal status at the time of writing this paper. Such society members were mentioned were for the sake of promoting conversation. These individuals include: Takezaki Kuniyaki “Neko Hiroshi,” Shimomura Osamu, Donald Keene, David Aldwinkle (有 道出人), and Shigenobu Fusako.

Takezaki Kuniyaki, a.k.a. "Neko Hiroshi” had to denounce his Japanese citizenship in order to petition for Cambodian citizenship. However, after not meeting the residency requirement for Cambodian citizenship, he has become temporarily stateless. Granted, his Japanese citizenship was reinstated. Dual citizenship, if offered, would prevent individuals from becoming stateless. Dual citizenship would be an asset to governments for tax purposes and for claiming notoriety based on the accomplishments of their citizens. Shimomura Osamu is a case example.

Shimomura Osamu after having lived and studied extensively in the United States at the University of Washington, Princeton University, Boston University School of Medicine and Marine Biological Laboratory, took on American citizenship through long-term residence. The Japanese government does not recognize dual or multiple citizenship. Taking on foreign citizenship is criteria to loosing Japanese citizenship. Shimomura Osamu after his studies with Professor Frank Johnson at Princeton University beginning in 1960 went on to naturalize when honored as professor emeritus at Boston University. Naturalization meant that his Japanese citizenship was annulled. Based on Japanese citizenship law Shimomura Osamu could not be an American citizen while claiming to also be Japanese. However, when Shimomura Osamu was awarded the Nobel Prize in Chemistry in 2008, his Japanese citizenship was never questioned by the Japanese government. As the news of the "Japanese" Shimomura Osamu being awarded the Nobel Prize worked its way around the international media, the foreign media and Internet news sites such as "Asia Cable" only briefly mentioned his U.S. citizenship. Recently, selective amnesia has taken over the media, as his Japanese citizenship has been reestablished.

Fusako Shigenobu, the founder and former leader of the Japanese Red Army terrorist group, after spending 30 years in the Middle East and possessing and forging passports, somehow maintained her Japanese citizenship. She was tried as a Japanese citizen upon her arrest in Osaka in November 2000 and throughout her prison sentence in 2006 and 2010, her Japanese citizenship was assumed. May Shigenobu, the daughter of Red Army terrorist Fusako Shigenobu, entered Japan on a counterfeit passport, but instead of being arrested for illegal entry and deported, she was granted citizenship and the Japanese government provided her with a new 
passport.

David Aldwinkle (有道出人), a writer and associate professor at Otaru University and a columnist for Japan Times was granted Japanese citizenship, but at the time of this writing, David Aldwinkle is a resident of Canada. Although the media maintains his claim to Japanese citizenship, his current legal status and citizenship are otherwise unknown by the author.

The Japanese literary scholar Donald Keene, after his many years of Japanese literary research and writing announced his interest in taking on Japanese citizenship in the wake of the March 2011 earthquake and tsunami in Tohoku. However, taking on a Japanese name as currently required for Japanese citizenship has forced Donald Keene to have reservations about sacrificing the name he worked his entire life and career to build. Petition to use his ateji nickname 鬼怒鳴門 was the last the author heard of Donald Keene’s citizenship mentioned in the media. However, online news sources confirm that Donald Keene has acquired Japanese citizenship. Moreover, Donald Keene has gone on to write the book watashi ga nihonjin ni natta riyuu - nihongo ni miserarete 私が日本人になった理由一日本語に魅せられて detailing his reasons for taking on Japanese citizenship.

Tama-chan, although not a human being, is a Japanese citizen by legal definition. It is baffling to believe that a male bearded seal-an entirely different species of organism would be granted political acceptance and citizenship; however, Tama-chan has a juminhyo registered to Yokohama City, Nishi-Ward. Moreover, fictional entities including animated cartoon characters such as "Chibi Maruko-Chan" and "Crayon Shin-Chan" are also Japanese by legal definition. Saitama Prefecture Niiza and Kasukabe Cities have granted fictional animation characters such as Crayon Shin-Chan a juminhyo.

If one is adored by society, has Japanese blood through established lineage or is deemed by the government to be an asset to society, such an individual is readily absorbed into society and accepted both socially and politically as a Japanese citizen. Examples of foreign athletes or award winners being quickly granted citizenship or permanent residency over foreign residents that have spent their whole lives petitioning for acceptance makes one realize the capriciousness of both the Japanese government's standard for granting citizenship as well as public's biased criteria for social acceptance.

The author's own experience of petitioning for permanent residency and the struggles associated with the government's selection process has convinced him that the true criteria for citizenship is less than transparent. The lawyer that helped the author gain permanent residency reconfirmed this viewpoint as the author was informed that the profit one provides for the country is debatably the true and only judging criteria for obtaining permanent residency.

Statelessness is also a social issue that concerns social and political acceptance of the citizenship of society members. Although statelessness or mukokuseki 無国籍 exists in Japan and Korea, it is rarely covered by the media nor readily acknowledged by the government. Stateless society members are potential candidates for discrimination beyond measure as they are not given protection from any government (Chen, 2012). Although considered an uncommon social issue, statelessness has been researched by social anthropologists. Neither the Korean government nor the Japanese government have offered a permanent solution to statelessness nor are willing to grant citizenship based on mere residence as blood ties also stain political criteria for who belongs in society.

Likewise, the governments of Japan and Korea not accepting multiple citizenship is perhaps the root of the problem determining belongingness and marginality in Japan and Korea. The author believes firmly that a governmental acceptance of multiple citizenship would end the problem of statelessness in Japan and Korea as well as creating an avenue for social acceptance of marginalized citizens. Moreover, as the population in Japan declines through the low birth rate or 少子化 shoshika, the acceptance of dual citizenship would potentially end the population crisis as many reentry Japanese who have family abroad and permanent residents who do not desire to relinquish their homeland citizenship in order to naturalize or are politically unable to renounce their former citizenship would be able to join Japan's official population as citizens. A more comprehensive study of statelessness and dual citizenship and its legal implications would provide perspective and further add to criteria on proving and establishing personal identity. Statelessness and non-acceptance of dual citizenship is perhaps another manifestation of how multiracial residents of Japan and Korea are marginalized.

Relinquishing citizenship for United States citizens has become increasingly expensive. As Wood (2015) wrote for Forbes, the United States has the world's highest fee to renounce citizenship. The U.S. State Department raised the fee $422 \%$ from $\$ 450$ to $\$ 2,350$. This rate is more than twenty times the average level in other high-income countries (Wood, 2015). According to researcher Cann (2016) this is extremely high when considering that there is no fee for taking on citizenship nor renouncing citizenship in Japan and that it only costs $\$ 20$ to renounce citizenship in South Korea (Cann, 2016). In addition to the fee for renouncing citizenship, there is now a heavy "exit tax" imposed on U.S. Citizens renouncing citizenship. 
The United States is the only country in the world besides Eritrea that levies taxes based on citizenship rather than on residence or the source of revenue. The author, as an American citizen by birth, having spent most of his life abroad - which amounts to almost 25 years abroad as an expatriate in Asia, pays taxes to the country that he resides in, but still has to go through the complex process of filing IRS returns. The author doesn't make enough money to owe tax in the U.S.-in fact, he continually pays more to CPA tax preparers than he owes in tax.

Long-term expatriated American colleagues have given up their citizenship only to avoid the stress of filing such paperwork on taxes. This is not tax evasion, since it is not about the tax expatriates owe, but rather the burden of filing and fear of penalties that often make United States expatriates question the merit of maintaining U.S. citizenship. U.S. Foreign Account Tax Compliance Act (FATCA) is now reaching across the ocean and digging into U.S. citizen's pockets to pay taxes on savings that such citizens have already paid taxes on. Taxed to relinquish citizenship and taxation based on citizenship instead of income or residence is a concept that neither Japanese nor Koreans can relate to, but is an essential factor when considering the requirements for relinquishing citizenship to legally naturalize in Japan or Korea.

\section{Interpretation of Student Survey Data}

Students' opinion suggest a strong correlation between race and the acceptance of being Japanese. Individuals of mixed lineage (Rie Miyazawa, etc.) were readily accepted as Japanese. Moreover, zainichi eijusha (在日永住者) permanent residents or those who are not citizens but are Japanese in appearance (Sadaharu Oh, Akiko Wada, etc.) were almost unanimously voted as being Japanese even without Japanese citizenship.

However, Japanese language ability is also regarded as a social criteria for establishing "citizenship." Alberto Fujimori, even with Japanese lineage and Japanese in appearance was not granted full acceptance as Japanese due to his lack of Japanese language ability. Nevertheless, the author was granted Japanese citizenship by a portion of the students. Upon inquiring about the reason, the students polled indicated that the decision was due to his language abilities. Students also interpreted the author asserting an assumed Japanese citizenry as the intent of the poll. Opinion would no doubt be skewed if the students had met the author for the first time or judge the author based on his Western appearance. The Hawthorne effect might also be observed if the poll was conducted by a native Japanese instead of an individual Western in appearance.

\section{Conclusion: To Be or Not to Be}

Having Japanese language ability is the qualifier to "entitlement" of social acceptability; however, it is physical appearance that is immediately endorsed. Language ability alone is not enough to convince all of society into social acceptance. Moreover, having to prove one's language competency with every society member one encounters is a never-ended task.

Citizenship is not merely a matter of legal status nor is it something earnable as Japanese citizens of nonAsian lineage are condemned to unchangeable conditions such as blood or birth. Western lineage Japanese citizens are condemned to live out their lives in Japan as perpetual foreigners. Ascribing something as important as personal identity, nationality and citizenship only to lineage and blood ties can only serve to hurt Japanese society to ostracize and alienate Japanese citizens of international lineage.

Although socially an invisible minority, multiracial Japanese and Koreans are increasing in society. Viewed as a social curiosity, the few known "visible" multicultural Japanese and Koreans dot the modern social landscape as TV "talents" and athletes. Although not commonly mentioned, the media shows occasional interest in the social and political acceptance of multiracial citizens.

An individual's race or ethnic orientation tends to be the sole concept that is a determining factor for social acceptance and societal acknowledgment of citizenship. This is also true for Western nations as well. The author's casual observation of social media forums on the subject of racism and race-based hate crimes suggest that racism and "othering" of minority groups exists everywhere there are human beings. Groups and individuals struggling for social acceptance and citizenship exist in every society. Racism exists as a result of labeling and stereotyping. Race and racism, are both constructed concepts-neither are scientific nor biologically valid. It is morally wrong for an individual to be defined or limited by the ignorance and prejudices of other people (Flake, 1999).

Ethnocentricity, in other words, the "it's easier to deal with my own kind" way of thinking is a value held in some degree by all societies. However, both Japanese and Koreans appear to have a great ethnocentric sense because the society value is placed on conformism and collectivism which foster a taste of togetherness (Lebra, 1996) Moreover, the hypothesis of the influences of living in a relative homogenous society has extremely strong social implications. 
The author feels that Japanese and Koreans are the ones who decide who are Japanese and Korean while cultural anthropologists, sociologists, researchers, and educators are left to hypothesize and ponder about the reasons and criteria for judgment.

The author is in agreement with the mindset of many modern social anthropologists that Asians in general enforce belonging on a societal level and that unambiguous belonging is a key factor of determining who is Korean or Japanese and who is not. Paradigm shifts are common throughout history and perhaps as the Japanese and Koreans become more tolerant and educated concerning the multi-cultural demographic changes within their nations, a newfound acceptance for marginal societal members and citizenship based on criteria other than ethnicity will take root.

Diversity within the concept of race and culture is a strength. If we were all the same, it would be a boring world to live in. Being different and diverse provides uniqueness and dimension to all humans. Likewise, the differences are what affords all members of this global society an opportunity to learn from each other. When considering racial classification, perhaps it is best to be colorblind and classify humans on a basis of who we are as individuals and not by the vague concepts of race or language.

\section{References}

Arudo, D., 2007. What is “A Japanese”? Perspectives of a Naturalized Japanese. Presentation for International Christian University.

Blakemore, C. and S. Jennett, 2001. Albino: The Oxford Companion to the Body. Online. Internet. Retrieved from http://www.encyclopedia.com/topic/albino.aspx [Accessed September 14, 2013].

Cann, H., 2016. MAP: Dual Citizenship Around the World. Retrieved from http://www.movehub.com/blog/dual-citizenship-aroundthe-world-map [Accessed January 1, 2017].

Cavalli-Sforza, L.L., 1991. Genes, peoples and languages. In: Biological anthropology. Mountain View: Mayfield Publishing Company. pp: $163-170$

CBS News, 2015. Beauty queen brings light to Japan's racial issues. CBS News. Retrieved from http://www.cbsnews.com/news/meetariana-miyamoto-first-biracial-miss-universe-japan/ [Accessed August 1, 2017].

Chen, T., 2012. Statelessness in Japan: Management and challenges. Journal of Population and Social Studies, 21(1): 70-81. View at Google Scholar

Flake, F., 1999. The way of the bootstrapper: Nine action steps for achieving your dreams. New York: Harper Collins Publishers Inc. pp 10.

Flake, S.G., 1998. The skin I’m In. London: Corgi Books Press.

Franti, M., 1994. Socio-genetic experiment. In: Disposable heroes: Hippocracy is the greatest Luxury. CD: \#162-440-541-2. New York: 4th and Broadway Records.

Freilich, M., 1972. The meaning of culture: A reader in cultural anthropology. Lexington: Xerox Publishing Company. pp:100-103.

Fritzpatrick, M. and T. Macfarlan, 2015. 'I've been called n****r and had trash thrown at me': First mixed race Miss Japan hits out at the 'spasmodic vomit of racial abuse' she's suffered because father is African-American. Retrieved from http://www.dailymail.co.uk/news/article-3021032/First-mixed-race-Miss-Japan-Ariana-Myamoto-hits-spasmodic-vomitracial-abuse-suffered-father-African-American.html [Accessed August 1, 2017].

Hindustan Times, 2016. Half-Indian Priyanka Yoshikawa crowned Miss Japan, but not everyone's impressed. Retrieved from http://www.hindustantimes.com/world-news/half-indian-priyanka-yoshikawa-crowned-miss-japan-but-not-everyone-simpressed/story-jXYLOiLgj6aC4x36xMtYNM.html [Accessed August 1, 2017].

Horton, P.B., 1976. Race and ethnic relations: An introduction to sociology. 4th Edn., New York: McGraw-Hill Book Company. pp: 333336.

Japan Times, 2016. Japanese-Indian crowned Miss Japan, Drawing mixed reaction. Japan Times. Retrieved from http://www.japantimes.co.jp/news/2016/09/05/national/social-issues/woman-of-indian-descent-crowned-missjapan/\#.WX_cOoePU_t [Accessed August 1,2017].

Keene, D., 1999. Living in two countries. Tokyo: Kodansha International Ltd. pp: 156-161.

Klass, M., 1971. The kinds of mankind: An introduction to race and racism. New York: J.B. Lippincott Company. pp. 12-21.

Kondo, D.L., 1990. Crafting selves: Power, gender, and discourses of identity in a Japanese workplace. Chicago: University of Chicago Press.

Lebra, T.S., 1996. Japanese patterns of behavior. Honolulu: University of Hawaii Press.

Lies, E. and S. Ito, 2015. Multiracial Miss Japan hopes to change Homeland's thinking on identity. Reuters. Retrieved from https://www.reuters.com/article/us-japan-beauty-multiracial-idUSKBNoMToTU20150402 [Accessed August 1, 2017].

Maged, N.K., 1997. Dermatology society. Anatomy of the skin. Retrieved from http://telemedicine.org/anatomy.htm\#Keratin ¿Accessed November 15, 2005].

Marks, J., 1995. Black, white, other. In: Biological anthropology. Mountain View: Mayfield Publishing Company. pp. 159-162.

Matsui, Y., 1992. 外国人から見た日本語一正 しい日本語が分かりやすい. Nihon Kyobunsha Shuppan.

Moeran, B., 2007. Ethnography at work. Oxford: Berg Publishers.

Moeran, B. and J. Valentine, 1992. Unwrapping Japan: Society and culture in anthropological perspective. Honolulu: University of Hawaii Press.

Nagata, M., 2015. Not Japanese Enough? Miss Universe Japan Looks to Fight Prejudice. Kyodo News. Retrieved from http://www.nichibei.org/2015/08/not-japanese-enough-miss-universe-japan-looks-to-fight-prejudice/ [Accessed August 1, $2017]$.

Nakazawa, D.J., 2003. The changing faces of America: What young people of mixed-race can tell us about the future of our children. Sunday, July 62003 edition of Parade Magazine. New York: Parade Publications.

Newsweek, 2006. The new face of Japan: Foreigners are not only coming-They're staying. Special Report on Immigration. Newsweek Magazine. 
Relethford, J.H., 1996. The biology and behavior of the living primates. In: The human species An Introduction to biological anthropology. Mountain View: Mayfield Publishing Company. pp. 353-407.

Relethford, J.H., 2012. Human population genetics. 1st Edn., Wiley-Blackwell Published 2012 by John Wiley \& Sons, Inc. pp: 2-6.

Richards, J., 1998. University of California. Internet. Retrieved from http://medicine.ucsd.edu/pathology/ som213/skin2.html [Accessed November 15, 1998].

Rose, P.I., 1986. Race and ethnicity. In: Sociology: Inquiring into society. San Francisco: Canfield Press. pp: 228-239.

Thomas, L., 2007. Turning white: A memoir of change. New York: Momentum Books.

Wesby, M., 2015. Japan's Problem with Race. Newsweek. Retrieved from http://www.newsweek.com/why-does-no-one-care-japaneseare-openly-racist-364129 [Accessed August 1, 2017].

Wood, R.W., 2015. U.S. Has world's highest fee to renounce citizenship. Forbes. Retrieved from http://www.forbes.com/sites/robertwood/2015/10/23/u-s-has-worlds-highest-fee-to-renounce-citizenship/\#65584ae26568 [Accessed January 1, 2017].

Citation | Lee Hatch Flake (2017). A Critical Look at Race and Language as a Method of Establishing Personal Identity in Japan and Korea. International Journal of Social Sciences and English Literature, 1: 5-15.

\section{History:}

Received: 4 August 2017

Revised: 18 September 2017

Accepted: 22 September 2017

Published: 25 September 2017

Licensed: This work is licensed under a Creative Commons

Attribution 3.0 License (cc)

Publisher: Eastern Centre of Science and Education
Funding: This study received no specific financial support.

Competing Interests: The author declares that there are no conflicts of interests regarding the publication of this paper.

Transparency: The authors confirm that the manuscript is an honest, accurate, and transparent account of the study was reported; that no vital features of the study have been omitted; and that any discrepancies from the study as planned have been explained.

Ethical: This study follows all ethical practices during writing.

Eastern Centre of Science and Education is not responsible or answerable for any loss, damage or liability, etc. caused in relation to/arising out of the use of the content. Any queries should be directed to the corresponding author of the article. 